Counsellia: Jurnal Bimbingan dan Konseling, 9(1), 2019 | 1 - 13

Copyright (C2019 Universitas PGRI Madiun

ISSN: 2088-3072 (Print) / 2477-5886 (Online)

Available online at: http://e-journal.unipma.ac.id/index.php/JBK

DOI: $10.25273 /$ counsellia.v9i1.3209

\title{
Faith-Base Communities (FBCs) in Ecological Counseling (EC) to Promote Well-Being (WB) in Millenial Era
}

\author{
Moh. Khoerul Anwar ${ }^{1}$, Ruly Ningsih ${ }^{2}$ \\ ${ }^{1}$ Bimbingan dan Konseling Islam, Universitas Islam Negeri Sunan Kalijaga, \\ Yogyakarta \\ moh.anwar@uin-suka.ac.id \\ ${ }^{2}$ Program Pascasarjana, Universitas Negeri Yogyakarta, Yogyakarta \\ ruly.ningsih2016@student.uny.ac.id
}

\begin{abstract}
Abstrak
Kesejahteraan psikologis merupakan kajian yang populer dikalangan peneliti. Kajian ini berkatian dengan beberapa perubahan di era milenial. Artikel ini bertujuan untuk menjelaskan mengenai komunitas beragama yang dapat berfungsi sebagai alternative untuk mempromosikan kesejahteraan psikologis di era milenial. Data yang diperoleh dalam penulisan artikel ini dilakukan dengan melakukan kajian literatur. Hasil kajian ini menunjukkkan adanya beberapa bukti bahwa komunitas beragama dapat menjadi kolaborator penting dalam menyampaikan misi moralitas dan misi tercapainya kesejahteraan psikologis di masyarakat. Implikasi temuan ini terhadap profesi konseling yaitu agar konselor memiliki komptensi ekologis yang akan membantunya memiliki paradigma multukultural, maupun pengembangan kerangka intervensi sistemik.
\end{abstract}

Keywords : Ecological Counseling; Faith-Base Communities; Well-Being

\begin{abstract}
Well-being are the populer issues among academic researchers. This issues related to any change in millennial era. This article aimed to explain how faith-base community $(F B C s)$ could promote well-being (WB) in millennial era. Data gathered by literature study included journal articles and books. The results of the study indicated that the efforts to promote well-being wellbeing could be done with collaborative efforts of counselors with faith communities. There were many evidence showed that faith-base community $(F B C s)$ could be important collaborators to deliver a mission of morality and bring the mission of promoting psychological well-being (WB) in society. The implication of the study that counselors had to have the ecological competences that could lead the counselor to the multicultural thinking paradigm, as well as the development of the systemic intervention framework.
\end{abstract}

Keywords : Ecological Counseling; Faith-Base Communities; Well-Being

\section{PENDAHULUAN}

Kesejahteraan psikologis merupakan hal yang utama dalam kehidupan masyarakat. Kesejahteraan psikologis memiliki peranan penting karena orang yang sehat dan sejahtera psikologis akan semakin produktif dan mampu bekerja dengan baik. Lain halnya jika orang yang mengalami gangguan 
kesejahteraan psikologis, tentu akan berdampak kurang baik dalam bekerja, bersosial, bermasyarakat dan dalam menjalani hidup. Hal ini sejalan dengan hasil penelitian (Aden Rahmat Afrianto, Binsar Siregar, Insan Firdaus, 2015) bahwa adanya hubungan yang signifikan antara kesejahteraan psikologis dengan kepuasan dalam bekerja. Sejalan dengan hal tersebut, peneliti lain (Yansasputri \& Wijaya, 2017) menemukan bahwa kesehatan sosialemosional berhubungan dengan capaian akademik mahasiswa. Penelitian tersebut menjelaskan bahwa orang yang memiliki kesejahteraan psikologis mampu melakukan pekerjaannya dengan baik dan memiliki kepuasan kerja yang tinggi. Hal ini dikarenakan orang yang memiliki kesejahteraan psikologis akan menjalani hidup dalam lingkungan yang menarik, menyenangkan, bahagia dan penuh dengan tantangan serta menunjukan kinerja secara optimal.

Pembahasana kesejahteraan psikologis di era milenial telah menjadi perhatian penting khususnya bagi para akademisi. Konsep kesejahteran psikologis dari menemukan kerangka konseptual sampai dengan upaya intervensi (Dodge, Daly, Huyton \& Sanders: 2012; Huppert \& So, 2013). Salah satu langkah yang dapat dilakukan dalam membantu kesejahteraan psikologis individu adalah intervensi. Intervensi yang dimaksud adalah intervensi pencapaian kesejahteraan psikologis yang dilakukan dengan melibatkan elemen kebermaknaan, refleksi, berbagi pengalaman, dan pembelajaran secara kelompok kecil (West, et all, 2014). Intervensi dalam membantu kesejahteraan psikologis berprinsip pada konsep intervensi dalam konseling, dimana ketika individu yang tidak sejahtera di arahkan dan dibantu agar sejahtera dengan intervensi-intervensi tertentu dalam konseling. Selanjutnya, strategi dan intervensi yang diterapkan dalam konseling juga beragam jenisnya. Hal ini dikarenakan adanya pergeseran paradigm dalam konseling. Abad 21 mulai tampak jelas bahwa lingkungan membatasi perilaku manusia (Lewis, Lewis, Daniesl \& D'Andrea, 2010). Adapun salah satu strategi dan teknik yang digunakan dalam konseling adalah konseling ekologis. Konseling ekologis merupakan strategi yang menghubungkan antara personal dan lingkungan.

Model ekologis merupakan kajian yang populer dikaitkan dengan upaya intervensi. (McMahon, Masson, Dalug-Guenther, dan Ruiz, 2014) mengkaji mengenai model ekologis dalam konteks penerapan konseling pada komunitas sekolah. Model ekologis dipandang penting karena adanya populasi yang beragam di sekolah yang harus dilayani oleh konselor. Menurut (McMahon, Mason, Daluga- 
Guenther, \& Ruiz, 2014) kerangka ini juga dipandang menawarkan perspektif baru bagi konselor sekolah untuk bekerja dengan melibatkan level yang berbeda-beda dan berbagai stakeholder yang memiliki kepentingan untuk bersama-sama untuk menjalankan fungsi sekolah. Selain itu, (Leonard et.al., 2011) juga mengkaji mengenai kerangka kerja ekologis untuk memahami relasi komunitas. Kajian tersebut mempersoalkan dampak kehadiran lulusan, dan angka putus sekolah. Peneliti memandang bahwa relasi yang sukses antarkomunitas akan mencapai "cultural cohesion" dengan membangun kolaborasi bersama pihak-pihak yang dekat dengan diri siswa. Selain dikembangkan dalam konteks sekolah, konseling ekologis juga berkembang dalam konteks komunitas di masyarakat. Model ekologis juga salah satu upaya intervensi yang penting sejalan dengan semangat dan paradigm bimbingan dan konseling yang komprehensif (Hidayat, 2016).

Pelibatan komunitas beragama sebagai kolaborator untuk mendukung suatu program telah populer dilakukan. Pihak yang dilibatkan mulai dari institusi pemerintah maupun institusi lain. (Cashman et al, 2012) mengatakan bahwa komunitas dipertimbangkan sebagai cara untuk mengembangkan komunitas dan upaya preventif terhadap suatu penyakit. Selain upaya prevenstif penyakit, hasil penelitian (Boddie, 2002) juga menunjukkan peran komunitas dalam membangun sinergi dengan pemerintah untuk untuk menyampaikan layanan yang ditujukan pada masyarakat luas. Penelitian lain menemukan bahwa komunitas juga berperan untuk menguatkan kesejahteraan psikologis. Komunitas dan proses secara organisasi yang memberdayakan secara psikologis memungkinkan suatu pendekatan untuk tersedianya kesejahteraan psikologis secara subjektif (Christens, 2012). Berdasarkan pada kajian tersebut, tampak bahwa kontribusi komunitas untuk melakukan perubahan pada diri individu perlu dipertimbangkan. Sejalan dengan fenomena yang telah terjadi, maka artikel ini berupaya untuk membahas mengenai cara kerja konseling ekologis yang didasarkan pada komunitas beragama sebagai upaya promosi kesejahteraan psikologis di masyarakat.

\section{METODE PENELITIAN}

Metode penulisan artikel ini berbasis studi dokumen. Artinya artikel ini ditulis dengan memanfaatkan studi literatur seperti buku dan jurnal. Topik-topik yang dibahas dalam buku dan jurnal tersebut meliputi komunitas agama, konseling ekologis, kesejahteraan psikologis dan era millennial. Buku dan jurnal yang digunakan dari tahun 
1979-2017. Sedangkan buku yang dijadikan kunci utama adalah buku The Ecology of Human Development. Buku ini menjadi rujukan utama berkenaan dengan teori konseling ekologi.

\section{HASIL DAN PEMBAHASAN Promosi Kesejahteraan Psikologis}

Promosi kesehatan telah menjadi kajian menarik sejak beberapa dekade lalu. Diri yang sehat tidak hanya dipandang dari segi fisik tetapi meluas pada aspek psikologis (Berry, Poortinga, Segal \& Dasen, 2002). Berkaitan dengan promosi kesehatan mental, studi lintas budaya menunjukkan adanya perbedaan kesejahteraan psikologis di berbagai negara. Kesejahteraan psikologis menunjukkan bahwa tingkat perkembangan ekonomi, kualitas kesehatan, maupun sistem pendidikan (Wells, 2010). Dengan kata lain, promosi kesejahteraan psikologis memiliki peranan penting dalam menjalani hidup. Semakin tinggi kesejahteraan psikologis individu, semakin baik pula kepuasan hidup yang dijalani oleh individu tersebut.

Kesejahteraan psikologis juga dikaitkan dengan aspek lingkungan. Kesejahteraan psikologis berkaitan dengan kelompok, budaya, keluarga, komunitas lintas budaya, maupun sekolah (Leddy, 2006). Senada dengan hal tersebut, Bronfenbreneur memandang bahwa karakteristik bawaan sejak lahir dan ekosistem yang melingkupi seseorang menentukan perkembangan seseorang dan kesejahteraan psikologisnya (Wells, 2010). Lebih lanjut, Bronfenbreneur menjelaskan bahwa kesejahteraan psikologi anak dan remaja didasarkan pada kualitas lingkungan sosial yang ditentukan oleh faktor hubungan orangtua dan orang dewasa yang berpengaruh, teman sebaya di tetangga dan sekolah, dan guru di sekolah. (Garbarin dalam Wells, 2010). Hal ini menunjukkan bahwa peran oranglain yang berada di sekitar tidak dapat diabaikan. Individu berbagi perasaan, sikap, maupun persepsinya dengan orang-orang yang terdekat dengan dirinya. Hal ini sekaligus menunjukkan pentingnya peran ekologis bagi individu, terlebih untuk membantu meningkatkan kesejahteraan psikologis individu.

\section{Paradigma Konseling Ekologis di Era Milenial}

Paradigma konseling ekologis memunculkan dua dilema. Dilema terkait semangat kolaborasi, di sisi lain dilemma terkait tantangan konselor. Konseling ekologis menawarkan dua tantangan penting bagi konselor. Konseling ekologis menantang konselor berkaitan dengan pemahaman keberagaman. Hal ini sejalan dengan Rychlak (Everett L. Worthington, 1989) yang menjelaskan bahwa salah satu motif mendasar konseling yaitu scholarly. Scholarly mengacu pada motif untuk 
memehami perilaku manusia dan untuk memiliki kesadaran mengenai penyebab perilaku. Kedua, konseling ekologis menantang pengembangan kompetensi multikultural melalui validitas ekologis (Cook, 2012: 161). Cook juga menekankan bahwa pemahaman keberagama dan pengembangan kompetensi kultural dibutuhkan untuk membantu konseli agar memiliki kesejahteraan psikologis yang baik.

Konsep ekologi di era milenial memiliki peranan penting. Ekologi memunculkan cara pandang baru secara konseptual sampai dengan upaya intervensi. Teori ekologi menganggap bahwa perkembangan manusia merupakan hasil interaksi atau transaksi antar kekuatan internal dan eksternal. Selain itu, pandangan teori ekologi menganggap bahwa manusia relatif dipengaruhi oleh faktor-faktor luar. Manusia memulai kehidupannya dengan memberikan reaksi terhadap lingkungan dan interaksi yang menghasilkan polapola perilaku yang berperan dalam membentuk kepribadian.

Konsep ekologis pada dasarnya mengajarkan paradigma bahwa persoalan tidak dipandang sebagai sesuatu yang tunggal. Kesalahan individu bukanlah kesalahan individu itu sendiri, tetapi banyak variabel yang mungkin memiliki kontribusi secara sistemik. Kerangka kerja ekologis menawarkan perspektif baru terkait perkembangan manusia, lingkungan, dan interaksi manusia dan lingkungan (Bronfenbreneur, 1979: 2). Bronfenbrenner melakukan konseptualisasi terhadap Lewin yang berpandangan bahwa $\mathrm{B}=\mathrm{f}(\mathrm{P} \times \mathrm{E})$. $\mathrm{B}=\mathrm{f}(\mathrm{P} \times \mathrm{E})$ merupakan konsep kunci Lewin yang berarti bahwa perilaku manusia merupakan fungsi dari interaksi seseorang dengan konteks lingkungannya (Cook, 2006: 6). Lebih lanjut, Bronfenbrenner juga mengejelaskan mengenai konsep Lewin yang menawarkan tiga preposisi penting. Preposisi pertama, perilaku manusia dipengaruhi oleh karakteristik individu dan konteks tempat hidup. Preposisi kedua, perilaku manusia merupakan hasil dari interaksi diri dengan lingkungannya. Preposisi ketiga, perilaku manusia terbentuk melalui pemaknaan. Preposisi ini menyajikan kerangka kerja yang komprehensif bagi profesi yang menawarkan layanan psikologis seperti seorang konselor.

Konselor merupakan salah satu helper yang menawarkan jasa layanan konseling. Menurut UndangUndang Nomor 20 Tahun 2003 mengatakan bahwa konselor dalam konteks profesi di Indonesia salah satunya menyediakan layanan dalam seting pendidikan. Selain itu, konselor berperan sebagai individu yang membantu dalam memberikan pengenalan, pemahaman dan penyadaran terhadap indivoidu yang mengalami masalah. Secara perspektif ekologis, konselor 
memiliki peranan penting sebagai indvidu yang mampu meredesain perilaku-perilaku yang terjadi pada individu maupun masyarakat. Hal tersebut sejalan dengan pendapat Sue (Campbell1, Vance1 \& Dong, 2017) yang mengatakan bahwa model tripartite digunakan dalam pelatihan konseling yang ditujukan pada tiga karakteristik kritis konselor multikultural yakni kesadaran, keterampilan/skill, dan pengetahuan. Dengan demikian, konselor mampu melakukan redesain perilaku individu maupun masyarakat melalui pendekatan ekologis yakni memberikan pengetahuan dan penyadaran serta memberikan ketarampilan dasar konseling bagi individu di masyarakat.

Visi reformatif konseling ekologis sejalan dengan konseling pada umumnya, akan tetapi tetapi konseling ekolgis menyandingkan dengan konteks tempat individu melangsungkan kehidupannya. Konseling ekologis bertujuan untuk membantu individu mengembangkan kehidupan yang memuaskan, produktif, dan bermakna melalui pemahaman mengenai bagaimana kehidupannya berakar dalam konteks yang beragam, interaksi dengan dunia sekitar konseli, dan proses pemberian makna terhadap kehidupannya (Cook, 2012:8). Konsep dan tujuan ini membawa implikasi bagi konselor dalam menjalankan praktik profesionalnya dalam membantu melayani individu dalam mempromosikan kesejahteraan psikologis individu..

Selanjutnya, Bronfenbrenner menyebutkan konsep inspiratif dari Piaget bahwa anak memiliki kapasitas untuk menciptakan dan membayangkan dunia yang merefleksikan pertumbuhan psikologisnya. Sebagaimana Piaget, perspektif ekologis menyetujui bahwa fantasi baik secara struktur dan perkembangan juga meluas mulai dari mikrosistem, mesosistem, eksosistem, dan mikrosistem. Mikrosistem merupakan struktur yang paling luas dalam strutktur ekologis. Konteks mikrosistem merupakan agen terdekat dari diri individu yang terdiri dari orangtua, teman sebaya, sekolah, lembaga agama, pelayan kesehatan, maupun tetangga (Bronfenbrenner, 1979: 10; Santrock, 2012). Berkaitan dengan hal tersebut, misi konseling ekologis adalah mengakomodasi perubahan diri konseli melalui pelibatan konteks lembaga agama atau komunitas beragama.

(Santrock, 2012:

menjelaskan bahwa lembaga agama merupakan salah satu komponen penting yang diperhitungkan dalam konteks mikrosistem. Lembaga agama terdiri dari orang-orang yang memiliki kompetensi agama. Sosok yang disebut significant others biasanya adalah ustadz, pendeta, rohaniawan atau pembimbing. Selanjutnya, anggota masyarakat yang tergabung dalam komunitas 
agama biasanya juga mengikuti misi-misi moralitas yang dibawa oleh kelompok agama atau sering disebut dengan komunitas beragama.Pada dasarnya kelompok menawarkan beberapa layanan. Beberapa layanan yang dapat ditawarkan kelompok yaitu proyek ketetanggan, pendidikan, agama, budaya, dan komunitas (Wuthnow and Evans dalam (Cook, 2010)). Komunitas beragama (faith-based communities/FBCs) dipandang sebagai anggota komunitas yang penting dan menjadi pusat dalam kehidupan konseli (Cook, 2012: 259). Dengan demikian, komunitas beragama memiliki peranan penting sebagai fasilitator dalam membantu untuk mempromosikan kesejahteraan psikologis individu maupun masyarakat. Hal ini dikarenakan setiap komunitas memiliki peran yang berbeda-beda dan komunitas beragama dapat menawarkan penyelenggaraan pertemuan untuk belajar tentang agama lain.

\section{Komunitas Agama Sebagai Agen Mikrosistem}

Sebagaimana yang telah dinyatakan sebelumnya bahwa komunitas beragama (FBCs) termasuk dalam komponen lapisan mikrosistem. Agen ini termasuk pada agen terdekat yang melingkupi diri individu sehingga dapat memberikan pengaruh langsung pada individu. Komunitas memiliki peran yang sangat membantu bagi konseli. Hal yang dapat dilakukan komunitas misalnya melakukan peran advokasi. Hal tersebut menjadi dasar bahwa peranan komunitas beragama untuk membantu mempromosikan kesejahteraan psikologis dapat dilakukan. Selain itu, konselor memandang bahwa pendekatan konseling ekologis berbasis komunitas beragama dirasa mampu untuk membantu mensejahterkan psikologis masyarkat. Hal ini dipandang karena ustadz, pembimbing, pendeta dan lainnya dalam komunitas beragama mampu menjadi agen perubahan. Lewis (Lewis, lewis, Daniels dan D'Andrea, 2010) memandang bahwa perubahan merupakan proses yang mensyarakan adanya visi, persistensi, kepemimpinan, kolaborasi, analisis sitem, dan data yang kuat. Lewis juga memandang bahwa konselor adalah orang yang tepat untuk mengambil inisiatif memimpin.

Selanjutnya, komunitas beragama tentu memiliki fokus tersendiri dalam agenda sosialnya. Fokus utama komunitas beragama adalah untuk memfasilitasi anggotanya dalam mengejar cara hidup yang berdasarkan prinsip agama/kepercayaan mereka. Cara hidup tersebut diberitahukan pada anggota dengan adanya komitmen bersama untuk meyakini tradisitradisi agama (Cook, 2012:260). Komunitas beragama mengajarkan ketaaatan pada Tuhan sekaligus 
menjadi institusi yang membawa misi moralitas dalam agenda dakwahnya. Dengan cara tersebut, diyakini mampu meningkatkan kesejahteraan psikologis masyarakat.

Misi moralitas yang dilakukan oleh komunitas agama, membawa implikasi penting bahwa komunitas beragama perlu dipertimbangkan sebagai institusi yang dapat membawa perubahan sosial. kelompok beragama merupakan agen otonom yang menyediakan layanan sosial (Koenig, 2005). Pertimbangan komunitas beragama sebagai agen perubahan sosial karena Indonesia tidak mengakomodasi individu yang tidak memiliki keyakinan beragama. Sila pertama dalam landasan kehidupan di Indonesia mengajarkan masyarakatnya untuk memiliki keyakinan beragama. Berdasarkan kondisi tersebut maka konseling perlu memberikan perhatian akan adanya keterhubungan dengan keyakinan beragama.

Hal ini sejalan dengan kondisi di Amerika bahwa konseling memberikan ruang bagi munculnya keyakinan beragama. Penduduk Amerika melaporkan dirinya sebagai orang yang memiliki religiusitas (Everett L. Worthington, 1989). Pelibatan komunitas beragama juga berkaitan dengan peran penting yang dapat dilakukan oleh komunitas beragama. Komunitas agama memiliki peran yang lebih didorong oleh misi dari keyakinan beragamanya untuk melindungi dari kemalangan (Koenig, 2005). Sumber yang sama juga memberikan contoh bahwa kepedulian lembaga agama dalam menyediakan kepemimpinan, pendampingan teknis, pelatihan, dan menjadi sumber untuk menjadikan komunitasnya lebih efektif. Selain itu, keyakinan agama dan spiritualitas merupakan sumber untuk emosional dan dukungan sosial (Leddy, 2006). Karena pentingnya komunitas, maka upaya intervensi perlu dirancang sedemikian rupa untuk dapat tercapainya kesejahteraan psikologis masyarakat.

\section{Intervensi \\ Psikologis melalui Komunitas Beragama}

Upaya pemberian bantuan kepada konseli dibangun atas dasar kekuatan dan sumber daya yang merupakan prinsip pendekatan konseling komunitas (Lewis et al., 2010). Kekuatan dan sumber daya yang perlu dipahamai akan berkaitan dengan langkah-langkah intevensi. Cook menjelaskan bahwa konseling berparadigma ekologis dipertimbangkan sejak assessmen sampai dengan perencanaan layanan konseling (Cook, 2012). Pada tahap asesmen, konselor dihadapkan pada teka-teki mengenai apa yang akan dilakukan setelah menjalin hubungan dengan konseli. Pemahaman konseli tidak hanya diupayakan untuk melihat diri konseli sendiri tetapi juga mencakup asesmen lingkungan. 
Kerangka kelologi melihat kesehana dan gangguan dari aspek diri, lingkungan, dan interaksi antara diri dengan lingkungan (Cook, 2012).

Tabel 1

Asesmen Status Kesehatan Mental Berdasarkan Elemen

\begin{tabular}{|c|c|c|}
\hline No. & Elemen & Contoh \\
\hline 1 & Penampilan & baju, gaun yang dikenakan \\
\hline 2 & Perilaku & perilaku berkendara \\
\hline 3 & Cara berbicara & keras, lembut, kualitas pembicaraan \\
\hline 4 & Suasana hati & stabil, berubah-ubah \\
\hline 5 & Proses pemikiran & derajat dan jenis pemikiran yang kacau \\
\hline 6 & Isi pikiran & potensi kekerasan, delusi, fobia \\
\hline 7 & Persepsi & halusinasi, ilusi \\
\hline 8 & Kapasitas kognitif & atensi/perhatian, konsentrasi, memori, intelegensi \\
\hline 9 & $\begin{array}{l}\text { Penggunaan zat } \\
\text { psikoaktif }\end{array}$ & jenis, kuantitas, frekuensi, efek \\
\hline 10 & $\begin{array}{l}\text { Kesadaran dan } \\
\text { penilaian }\end{array}$ & $\begin{array}{l}\text { kesadaran akan asal dan sifat masalah, alasan dari suatu } \\
\text { keputusan }\end{array}$ \\
\hline
\end{tabular}

Beberapa hal yang muncul individu bukan atas kemauan pada tabel tersebut merupakan individu itu sendiri. masalah muncul bagian dari indikator-indikator untuk sebagai timbal balik atau mengasses lingkungan yang terjadi konsekuensi diri yang hidup pada masyarakat. Assesmen dilingkungan tertentu. Oleh sebab itu, lingkungan tersebut berguna sebagai Cook (2012) juga memberikan tolak ukur untuk mengetahui panduan untuk melakukan assessmen masalah-masalah yang terjadi terkait lingkungan.

kesejahteraan psikologis masyarakat.

Masalah-masalah yang dihadapi

Tabel 2

Status Penilaian Lingkungan Berdasarkankan Komponen

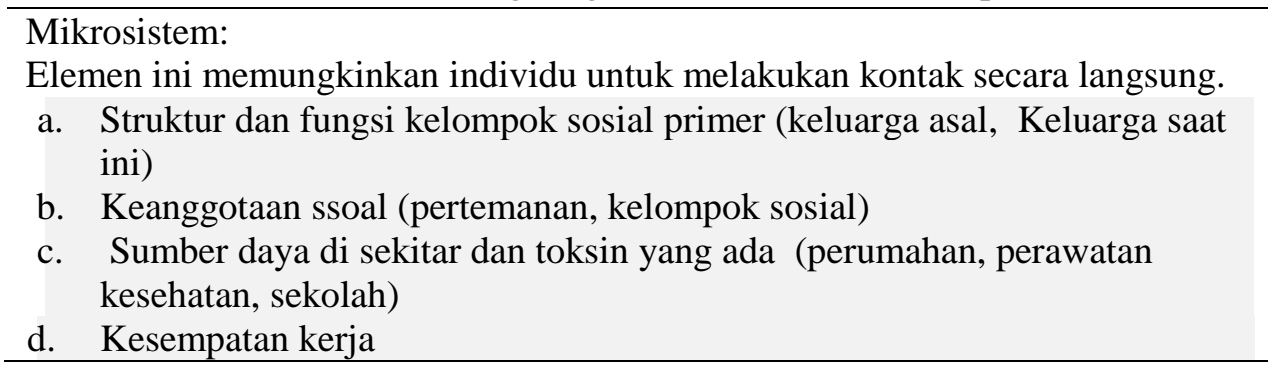


Eksosistem:

Elemen eksosistem yaitu sistem yang lebih luas yang mempengaruhi kehidupan konseli.
a. Kesempatan pendidikan
b. Pelayan kesehatan medis, perlindungan psikologis, perlindungan spiritual, perlindungan emosi
c. Keterlibatan dengan hukum/aturan

\section{Makrosistem:}

Maksrosistem merupakan daya sosial yang lebih luas yang mempengaruhi individu.
a. Kebudayaan, etnis, pertimbangan religi
b. Ketetanggaan, organisasi komunitas, dan pemerintahan
c. Kebijakan sosial politik dan dinamikanya.

Tabel tersebut menggambar bahwa setiap elemen baik mikrosistem, ekosistem dan makrosistem memiliki peranan dan komponen masing-masing dalam membantu individu untuk memiliki kesejahteraan psikologis yang lebih baik. Selanjutnya, melihat interaksi yang terjadi antara diri dengan lingkungan ekologi. Interaksi ini juga dipertimbangkan sebagai dasar untuk melakukan diagnosis. Secara lebih lengkap seperti tamak pada table berikut:

Tabel 3

Status Interaksi: Hirarki Pola Interpersonal
Bentuk sederhana dari Interaksi
a. Interaksi yang tidak resiprokal
b. Kontak singkat tanpa komitmen
c. Hubungan resiprokal tanpa tanggungjawab
d. Hubungan dengan kedekatan personal yang terbatas
e. Hubungan yang menyenangkan dan ko-evolusioner dengan komitmen yang mengikat.

Tabel tersebut menggambarkan bahwa status interaksi memiliki pola dan hubungan masing-masing. Setiap interaksi akan memiliki hubungan terkait antar individu. Oleh karenanya, status interaksi perlu dilakukan dengan cara yang baik sehingga mampu mengidentifikasi kondisi konseli dan lingkungan.

Langkah selanjutnya yang dilakukan konselor yaitu melakukan diagnosis mengenai masalah yang sebenarnya dihadapi oleh konseli. (Cook, 2012) mengatakan bahwa diagnosis mengenai hal-hal yang dihadapi konseli yang muncul dari diri konseli sendiri, problem yang muncul dari lingkungan, dan problem yang muncul dari interaksi antara keduanya.. Diagnosis digunakan sebagai dasar untuk melakukan intervensi. Selanjutnya, penetapan tujuan dipandang urgen sebagai bagian dari pengembangan persetujuan konselor dengan konseli mengenai hal yang akan diselesaikan dan cara penyelesaian problem. Tujuan yang ditetapkan tidak hanya tujuan umum, tetapi tujuan 
interpersonal, tujuan lingkungan, dan tujuan diri. Selain itu, konselor juga perlu menetapkan alat untuk perencanaan intervensi. Kunci penetapan tujuan dan perencanaan intervensi didasarkan pada kecocokan model antara konseli dengan perencanaan yang telah dilakukan (Rollnick, Mason, \& Butler dalam Cook, 2012). Cook menyarankan untuk menggunakan grounded problem guide yang dikemukakan oleh Wilson. Hal tersebut seperti tampak pada contoh berikut:

Tabel 4

Contoh Kerangka Masalah yang dihadapi Konseli

\begin{tabular}{llll}
\hline $\begin{array}{c}\text { Locus } \\
\text { Masalah }\end{array}$ & $\begin{array}{c}\text { P/Person } \\
\text { (content } \\
\text { insensitive) }\end{array}$ & \multicolumn{1}{c}{$\begin{array}{c}\text { P } \times \text { E } \\
\text { (Content } \\
\text { responsive) }\end{array}$} & $\begin{array}{c}\text { E/Lingkungan } \\
\text { (Content } \\
\text { Driven) }\end{array}$ \\
\hline $\begin{array}{l}\text { Social } \\
\text { distress }\end{array}$ & $\begin{array}{l}\text { Kurang memiliki } \\
\text { keterampilan } \\
\text { sosial }\end{array}$ & $\begin{array}{l}\text { Konflik dalam } \\
\text { hubungan dengan } \\
\text { teman }\end{array}$ & $\begin{array}{l}\text { Kehilangan } \\
\text { teman }\end{array}$ \\
\hline
\end{tabular}

Tabel ini menggambarkan bahwa setiap elemen memiliki peranan masing-masing berkenaan dengan kesejahteraan psikologis. Individu, orang lain dan masyaakat saling berkontribusi dalam proses pelaksanaan konseling ekologi berbasis komunitas beragama dalam membantu untuk mempromosikan kesejahteraan psikologis.

\section{SIMPULAN}

Era milinenial dicirikan dengan perubahan yang serba cepat dan berdampak pada psikologis manusia salah satunya aspek kesejahteraan psikologis. Kajian ini menunjukkan bahwa upaya promosi kesejahteraan psikologis upaya intervensi kesejahteraan psikologis perlu dilakukan secara sistemik. Konselor dapat melakukan dengan komunitas beragama sebagai upaya intervensi kesejahteraan psikologis. Hal ini berimplikasi pada kompetensi ekologis konselor. Keterampilan ekologis mencakup pemahaman multikultural konseli dan komunitas.

\section{DAFTAR PUSTAKA}

Afrianto, R. A., Siregar, B. \& Firdaus, I. (2015). Hubungan Antara Psychological Well Being (Kesejahteraan Psikologi) dengan Kepuasan Kerja pada PNS Dinas Sosial Provinsi Lampung. Jurnal Psikologi. Fakultas Psikologi, Universitas Bhayangkara Jakarta Raya

Berry, J. W., Poortinga, Y. H., Segall, M. H., \& Dasen, P. R. (2002). Cross-Cultural Psychology, Research and Applications (Second Edi). United State of America: Cambridge University Press.

Boddie, S. C. (2002). Fruitful Partnerships in a Rural African American Community: Important Lessons for FaithBased Initiatives. The Journal of Applied Behavioral Science, 
$38(3)$,

$317-333$.

https://doi.org/10.1177/0021886

302038003004

Bronfenbrenner, U. (1979). The Ecology of Human Develpment. Experiments by nature and design.

https://doi.org/10.1017/CBO978 1107415324.004

Cashman, R., Rhodes, S. D., Kelley, C., Sim, F., Alonzo, J., Mcguire, J., ... Reboussin, B. (2012). Using Community-Based Participatory Research ( CBPR ) to Develop a Community-Level HIV Prevention Intervention for Latinas: A Local Response to a Global Challenge, 3 . https://doi.org/10.1016/j.whi.20 12.02.002

Christens, B. D. (2012). Targeting empowerment in community development: a community psychology approach to enhancing local power and wellbeing, 47(4), 538-554. https://doi.org/10.1093/cdj/bss0 31

Cook, E. P. (2012). Understanding People in Context, the Ecological Perspective in Counseling. ASCA.

Dodge, R., Daly, A. P., Huyton, J., \& Sanders, L. D. (2012). The challenge of defining wellbeing, 2 , 222-235. https://doi.org/10.5502/ijw.v2i3. 4

Everett L. Worthington, J. (1989). Religious Fatih Across the Life Span: Implications for Counseling and Research. The Counseling Psychologist, 17(4), 555-612. Retrieved from tcp.sagepub.com

Hidayat, A. (2016). holistic Vision:
Integrative Approach in Guidance and Counseling Services. GUIDENA: Jurnal Ilmu Pendidikan, Psikologi, Bimbingan dan Konseling 6, (1). https://doi.org/10.24127/gdn.v6i 1.375

Huppert, F. A., \& So, T. T. C. (2013). Flourishing Across Europe: Application of a New Conceptual Framework for Defining Well-Being, 837-861. https://doi.org/10.1007/s11205011-9966-7

Koenig, H. G. (2005). Faith and Mental Health. Philadelphia: Templeton Foundation Press.

Leddy, S. K. (2006). Health Promotion, Mobilizing Strenghts to Enhance Health, Wellness, and Well-Being. Philadelphia: F. A. Davis Company Copyright.

Lewis, J. a., Lewis, M. D., Daniels, J. a., \& D'Andrea, M. J. (2010). Community Counseling: A Multicultural-Social Justice Perspective, 360. Retrieved from http://books.google.com/books?i $\mathrm{d}=\mathrm{yI}$ 67jM3BP_IC\&pgis=1

McMahon, H. G., Mason, E. C. M., Daluga-Guenther, N., \& Ruiz, A. (2014). An Ecological Model of Professional School Counseling. Journal of Counseling \& Development, 92(4), 459-471. https://doi.org/10.1002/j.15566676.2014.00172.x

Santrock, J. W. (2012). Life Span Development. Jakarta: Erlangga.

Undang-Undang Nomor 20 Tahun 2003 Tentang Sistem Pendidikan Nasional.

Wells, I. E. (2010). Psychological Well-Being. New York: Nova Science Publishers, Inc. 
West, C. P., Dyrbye, L. N., Rabatin, J. T., Call, T. G., Davidson, J. H., Multari, A., ... Shanafelt, T. D. (2014). Intervention to Promote Physician Well-being, Job Satisfaction, and Professionalism A Randomized Clinical Trial, 55905(4), 527533.

https://doi.org/10.1001/jamainte rnmed.2013.14387

Yansaputri, I. S. \& Wijaya, H. E. (2017). The Role of Social Emotional Health on Academic Achievent of college Student. GUIDENA: Jurnal Ilmu Pendidikan, Psikologi, Bimbingan dan Konseling 7, 1. http://dx.doi.org/10.24127/gdn.v $7 \mathrm{i} 1.748$. 